\title{
Discourse and 'Democracy': \\ Some Signals from the South African Corpus of English ${ }^{1}$
}

\author{
Robert de Beaugrande \\ Universidade Federal de Minas Gerais - FAPEMIG \\ Linda Pearce Williams \\ University of Port Elizabeth
}

O discurso público é repleto de termos cujos múltiplos significados divergem em função de estarem a serviço de diferentes ideologias. No discurso da "nova África do Sul", como comprovado no corpus recolhido recentemente, o temo "democracia" pode representar pelo menos três concepções: (1) uma doutrina de igualdade nos direitos humanos e nas liberdades civis e pessoais; (2) um sistema de "norma de maioria" através de uma engenharia eleitoral segura com múltiplos partidos e direitos universais de voto; e (3) um sistema de empresas livres e igualdade de oportunidades na economia e no mercado de trabalho. Estas concepções são totalmente incompatíveis, e, como os dados demonstram, a terceira idéia está destruindo a primeira.

Public discourse is replete with terms whose meaning is contested in the service of competing ideologies. In the discourse of the 'new' South Africa, as attested by a recently compiled corpus, the term 'democracy' is found to represent at least three conceptions: (1) a doctrine of equality in human rights and in personal and civil liberties; (2 ) a political system of 'majority rule' by means of a secure electoral machinery with multiple parties and universal voting rights; and (3) an economic system of free enterprise and equal opportunity in the economy and the job market. These are plainly incompatible, and, as the data show, the third one is currently undermining the first.

\section{What large corpora are telling us about 'language'}

Although large corpora have been available for over twenty years, their implications for our conceptions and theories of language have only recently begun to be acknowledged. This delayed impact has been at least partly due to the technology: corpora being still relatively small and the software for tagging and parsing the data relatively modest. Yet the delay also reflects the gradual and long-term evolution in the discipline of linguistics itself away from a soberly formalistic and 'purely linguistic' description of 'language by itself' (Saussure's 'langue', Chomsky's 'infinite set of sentences', etc.) toward a socially democratic and ecologically oriented exploration of language and discourse at the centre of human practices (see now synthesis in Beaugrande, 1997a). By using data from large corpora, we are now far better equipped to discover and interpret the multiple modes of evidence which might render the link between 'discourse' and 'democracy' an accredited issue for investigation. This evidence demonstrates the rich interconnectedness of language with the general and special purposes of human communication and interaction, extending well beyond the boundaries of any one conventional discipline in science or education.

One of the most important principles emerging from corpus work is that, to an impressive degree, a language is always in the process of being created and negotiated. As a corollary, the order of language does not persist in any static or 'synchronic' system - the 'language studied in and for itself" long ago declared by Saussure (1966 [orig. 1916]: 232) to be "the true and unique object of linguistics"- but undergoes continual evolution. A significant margin of the selections and combinations speakers and hearers perform are non-determinate on the plane of the system, and are determined only on the plane of the actual discourse. 
This principle has been widely overlooked by modern linguistics due to a curious dualism: equating language ('langue', 'system', 'competence' etc.) with order, whilst equating discourse ('parole', 'speech', 'performance' etc.) with disorder. We thus find Saussure (1966 [orig. 1916]: 14, 9, 11, my emphasis) announcing that 'language is a well-defined object in the heterogeneous mass of speech facts', whereas 'speech cannot be studied,' nor indeed can it be 'put in any category of human facts, for we cannot discover its unity'. The tenor was much the same when Chomsky (1965: 3f, 201, my emphasis) asserted half a century that 'linguistic theory is concerned primarily with an ideal speaker-hearer in a completely homogeneous speech-community, who knows its language perfectly', whereas the 'observed use of language' 'surely cannot constitute the subject-matter of linguistics, if this is to be a serious discipline', because 'much of the actual speech observed consists of fragments and deviant expressions of a variety of sorts'

The bolded items project a dualism whereby an orderly, unified system continually produces disorderly and disunified manifestations when speakers use the language; presumably, hearers perform the reverse transformation from disorder into order. Yet already as a mere thought-experiment, such a mode of operation seems both frankly implausible and utterly counter-productive. And, as has been repeatedly shown, large corpus data certainly display no such disorder; they display instead impressively fine-tuned modes of order, although those modes do not coincide with the idealised mode of order usually postulated and sought by conventional linguistics. Sinclair (1997a: 4) has thus recently surmised that 'many of well protected assumptions of language analysis are suspect and probably due for radical revision'.

To appreciate why, we should recall how much effort modern linguistics from Saussure to Chomsky has devoted to searching for an abstract, idealised (or 'underlying') order of language without deriving it from the evidence of authentic discourse data. Today, after nearly a century of such research, the various idealisations proposed to 'underlie' a language like English have so far managed to account for only small portion of the regularities of any real language like English and for a few well-behaved fragments of the 'grammar' or 'syntax'. Far from being uneasy at having achieved so little, linguists now proudly present a 'minimalist framework' (Abraham et al., 1996) whereby the intent to account for the bare minimum is expressly advertised as a hallmark of scientific status

Corpus data can now help us to appreciate why this total account has had to be so limited: a significant portion of the constraints upon the construction of linguistic units, including 'sentences', are not determined either by 'grammar' or by 'syntax' in the senses conventionally assigned to these two terms as sets of systems of 'rules'; speakers put words in various orders for many reasons, such as when things come to mind, what seems important or interesting, whom they are talking to, and so on. Nor indeed are these constraints determined by 'morphology', 'lexicon', or 'semantics' in their conventional senses. Instead, the constraints emerge from the continual interactions that co-ordinate those sets of selections and combinations which are relevant to the actual discourse (Beaugrande, 1997a). So each discourse merges the contributions of the standing constraints of the language (e.g., English puts the Article before the Noun, not after it) with the emergent constraints within the evolving context (e.g., politicians are debating how to transform a society from an 'authoritarian regime' into a 'democracy'; see section 2). Insofar as modern linguistics has sought to formulate just the standing constraints, it could only construct a fuzzy and incomplete vision of language.

A productive alternative outlook might be to define 'language' itself as a theory of human knowledge and experience, and to define discourse as the set of practices for working out the theory (cf. Halliday 1994). But we should at once qualify these definitions by stipulating that (a) a language is the richest and most comprehensive theory in the whole history of ideas; (b) unlike a scientific theory, the theory within a language allows for a huge set of competing alternatives without specifying which ones might (let alone must) be true or false; (c) a language as theory cannot be verified or refuted by controlled experiments, but only examined regarding the preferences it entails for expressing things in some ways rather than others; (d) the theory can always be modified by the practices of discourse without being at all discredited or refuted. In turn, discourse practices are not neatly circumscribed by the language as theory. Instead, they partially confirm it and partly move forward its evolution to accommodate a rich variety of contexts and circumstances. 
Yet discourse also constitutes a 'theory' about the objects and events constituting situations in the world, including the situation wherein the discourse itself occurs; a neat correspondence between what the discourse says and how the objects and events may be occurring 'in reality' cannot be taken for granted. On the contrary, the several participants may each be seeking to negotiate a version of 'reality' which holds adaptive value for their own goals, e.g., by giving the impression that those goals are natural, sensible, necessary, and so on. Still, testing the theory of the discourse against the practices with objects and events in a real situation is far more feasible and commonplace than testing the theory of the language against the practices of discourse on any large scale.

This layering of relations among theory and practice, as suggested in the graphic shown here,

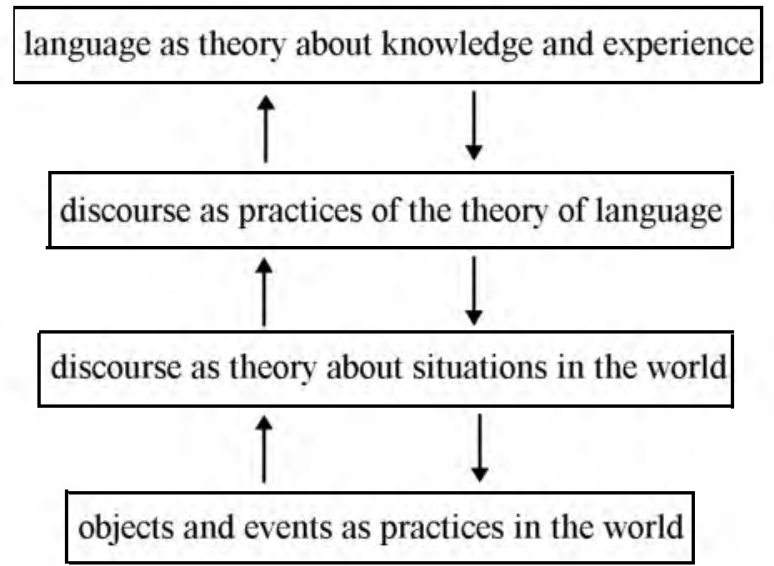

suggests that all our conceptions of language and of all its factors or components should be grasped in terms of $a$ dialectical interaction between theory and practice, and not as pertaining only to theory, as in formalist linguistics, or else only to practice, as in behaviourist psychology (cf. Beaugrande, 1998, 1999). Within a true dialectic, the theory should account for practices, whereas the practices should tune the constraints upon the construction and evolution of theories.

Of special concern here is the dual status of meaning as theory and practice. The meaning of a given word or expression needs to be grasped as one element situated within the total language that constitutes a theory of knowledge and experience, rather than just as one free-standing label or pointer for one equally free-standing object or event in the world. We can then explore how these meanings mutually constrain each other on the plane of the discourse and not just how any one meaning might be defined in isolation in terms of 'reference', 'denotation', and the other conceptions of semantics. Again, we can assume that the several participants in a discourse seeking to negotiate a version of 'meanings' which hold adaptive value for their own goals, e.g., by making them seem obvious, transparent, commonsensical, and so forth. Much of the negotiating is done without deliberate awareness to accommodate the remarkable speed and efficiency of discourse processing, and relies on the self-organising convergence of multiple constraints, as sketched above (see Beaugrande, 1997a for details).

Perhaps the most important parameter in the negotiation of discourse lies between inclusion and exclusion. In theory, a 'language' is by nature inclusive, just as 'communication' in actual discourse implies a 'community' and being 'shared in common' true to the etymology of the word. Yet precisely because differing goals can favour differing realities and meanings, many exclusive strategies have been elaborated for turning language and discourse back against themselves and converting fundamentally inclusive media into exclusive media, often without consciously acknowledging or intending the conversion.

The most obvious instances can be seen when groups of insiders are formed and seek to exclude outsiders by means of specialised language and discourse. The bases of such groups of course differ substantially - geography, religion, philosophy, science, youth cults, and much more - but they all modify their language and discourse to make it distinctive in ways that tends to include themselves and exclude outsiders. 
Less obvious but even more significant are the strategies for excluding people by making them feel incompetent through stigmatising their own language or language variety. These strategies are most widely practised by speakers of some prestigious language or language variety as an insidious means for safeguarding their own privileges without resorting to more forceful methods that could galvanise resistance (Beaugrande, 1998, 1999).

The speakers and advocates of some prestigious 'standard' variety will invariably claim that the 'standard' is more vital for communicating in ways that are 'clearer', 'more precise', 'more efficient', 'more intellectual', etc., than are other varieties, even when the main differences are merely phonetic. The account sketched here suggests that the really important factor is rather the advantages of 'standard' speakers to sustain an unquestioned dominance in the negotiation of realities and meanings during a discourse. Their versions sound more convincing, accurate, and accredited merely by virtue of the 'standardness' of their language, whereas the opposite holds for the versions of 'non-standard' speakers

In addition, the advocates of 'standard language' complacently assume that its features are clearly and universally defined. Yet actual corpus data indicate that its features are often fuzzy and disputatious. We should hardly be surprised, since a language naturally tends to manifest clines and bundlings of features as it evolves across times, places, and societies; and since numerous and diverse groups wish to claim the advantages of dominance over discourse. Indeed, fuzzy standards serve better than clear ones for impeding access of outsiders who might attempt to acquire the standard (Beaugrande, 1998, 1999).

The point for us today is not to claim that 'standard English' and similar notions simply don't exist, or that we should not make 'standard English' accessible for those who need or desire it. The point is that we would be undemocratic to call for 'standard English' and reward those who acquire it when we cannot rationally define its features and make them reliably accessible. To achieve that task, we will require comprehensive and authentic data about what people actually do say and write.

Past attempts to defines language standard have been impeded by at least two major factors. One factor was the prescriptivism and proscriptivism of many self-appointed language guardians who saw their mission in 'improving' the language over the ways it was used by 'the common people' or 'the vulgar mob'; the usages they declared to be 'bad English' or even 'not English' were naturally culled from the real usage of the language varieties they wished to stigmatise. These attitudes are by no means extinct today, though they may be camouflaged behind an avowed concern for 'clarity', 'precision', etc. etc., as noted above. But they are clearly undemocratic and irrational in claiming that what large sectors of the population really say is somehow not a proper part of the language. And the solution is not to prolong the hopeless and fruitless crusades for stamping out 'bad' usage, but to promote democratic and rational attitudes about language variation and language varieties (Gere \& Smith, 1979; Phillipson, 1992).

The other factor has been data limitations: the wide disparity between the totality of what was said or written during a given period (say a decade) and the amount an investigator or team could manage to collect and examine. This disparity is now being dramatically reduced by means of very large corpora stored in computerised data banks. To be sure, if a language is always in the process of being created and negotiated, no corpus, however large, can ever provide a complete picture; yet steadily larger corpora can enable us to achieve steadily closer approximations.

Within this perspective, discourse about 'language standards' and 'current usage' can finally be examined to see whether and how far the theory or language policy makers, language educators, and so forth, fits the practices. We can plausibly expect to find that the really clear-cut distinctions between 'standard' and 'non-standard' are by no means so numerous or general as has been typically implied by the language guardians, and do not significantly impair communication. For the vast majority of cases, the relevant distinctions are made between group-specific varieties characterised by such factors as age, social class, profession, hobby, education, and place of residence, where prescriptive notions like 'correctness' and 'grammaticality' are empty and inappropriate.

Because a very large corpus represents the versions of the language held by a very large population of speakers and writers, we also no longer need to depend upon the 'intuition' and 
'knowledge of the language' maintained by professional linguists of the various formalist schools, who have asserted that their own 'intuition' as 'native speakers' provides them with 'an enormous mass of unquestionable data' (Chomsky, 1965: 20). Admittedly, a corpus cannot give a complete picture of collective native-speaker-intuition any more than it can of the language itself. But those who work with corpus will soon notice that intuition is opportunistic: it cannot by any means predict all the options the corpus displays but it can usually make good sense of them after the fact (Francis and Sinclair, 1994).

The native speaker could thus be described as holding a competence that extends far beyond his or her own performance even over a very long time. As we have remarked, the speculative distinction set forth by Chomsky (1965) and others tends to equate 'competence' with order, and 'performance' with disorder. Corpus data suggest instead that 'competence' would be the native speaker's potential to achieve order, whereas 'performance' would be the manifestation of actually achieved order. This 'order' is precisely not the syntactic or semantic 'well-formedness' or 'grammaticality' defined in most of formalist linguistics to be a property of 'underlying structures' and not 'directly reflected' in 'surface structures'. It is a multiple order achieved by multiple dialectics between system and instance, between competence and performance, between regularity and innovation, and so on (Beaugrande, 1997a, 1998, 1999).

Moreover, the presentation of corpus data offers many opportunities to test one's own intuitions, whether of linguists or of more general language users: reacting to a sample actual corpus data by describing the probable context of situation; guessing what had just gone before or what is coming next; comparing the sample to what you might say, and so on.

These, then, are some of the things large corpora seem to be telling us about 'language', and some of the ways those things depart from conceptions of 'language' promoted by traditional language guardians and by modern linguists who had no access to large corpora. We can thus appreciate Sinclair's surmise, quoted above, that 'many of well protected assumptions of language analysis are suspect and probably due for radical revision'.

\section{'Democracy' as an evolving term and concept in South African discourse}

Now, how might these wide-ranging deliberations about 'language' and 'discourse' in light of corpus data relate to with our programmatic title, 'discourse and democracy'? For our own purposes, 'democracy' can be straightforwardly defined as a mode of human interaction on the basis of mutual equality and respect for human rights. The definition does not yield a clear-cut border between 'democratic' versus 'undemocratic', but rather a gradient between 'more democratic' versus 'less democratic'. Ideally, a 'democracy' should be deemed authentic only where equality and respect are accorded to all citizens, and not just to a dominant majority or voting block. That ideal may sound a bit utopian, since few of the officially proclaimed 'democracies' in the 'modern world' have actually achieved it. Yet if 'utopia is an unrealistic state to aspire to', 'the desire to approach it as closely as possible is realistic' (Owomoyela, 1996: 141). So democracy is best understood as a human space with unlimited potential for real advancement: if we can never arrive at utopia, we can always arrive at a closer approximation (Beaugrande, 1998, 1999). 'Democracy' can thus be defined as a mandate for steadily widening and deepening the inclusiveness of social practices to bring them closer and closer to the fundamental theory of democracy. Mutual equality and respect for human rights of a majority is clearly 'more democratic' than for the rights of a minority, but can only be one step on the way toward including steadily wider and more diverse sectors of the total population, including all minorities.

In theory at least, a 'language' should be a highly democratic system including the large community who possess it and share it among themselves. Moreover, unlike wealth or property, a 'language' can be shared with an indefinite number of new speakers without that community having to give up any of its possessions. Similarly, discourse should be a democratic activity insofar as it includes a wide range of speakers who are competent in the language. But in practice, just as language and discourse can be perversely deployed for exclusion, as remarked in section 1, they can also be 
rendered undemocratic to foment divisions among groups or between insiders versus outsiders. And this recourse can be expected particularly in societies where a 'democratic' constitution guarantees human rights for all races, genders, religions, and so on, but where the elites still fall back upon language as a pretext to preserve their special privileges.

Few ordinary speakers probably appreciate the extent to which discourse abounds with decisions either toward or away from 'democracy'; certainly, most speakers are unlikely to have been sensitised toward these decisions by conventional language education (Beaugrande, 1998). Yet at a deep level of awareness, many speakers and hearers are keenly attuned to subtle signals of equality and inequality in actual discourse practices.

The greatest challenge of all for language policy and language education would be to instil a lively sensibility and determination to support democracy in and through discourse and to put its theories of inclusion into practices of inclusion when the society is highly diverse in its cultures, languages, language varieties, religions, and so forth. Precisely such a challenge has been resolutely taken up by the government of South Africa since 1994. There, a broad consensus has been consolidated for transforming the society from an 'authoritarian regime' into a genuine 'democracy' (cf. sample [10] below). The new Constitution is a veritable model of democratic theory (cf. samples $[6-7,9]$ ), surpassing even the Constitutions of many older and more familiar 'democracies' such as the USA, where 'Equal Rights Amendments' to the constitution have been repeatedly voted down by the electorate and the legislatures or vetoed by a Republican President. If South Africa can put this theory into correspondingly democratic practice, it will set a historic example for other nations in transition.

One valuable resource for exploring the social, political, and cultural evolution of South African society during this crucial stage might be found in the South African Corpus of English, which has recently been established at the University of Port Elizabeth under the supervision of Chris Jeffrey. This corpus was originally inaugurated as part of the International Culture of English (ICE) under the direction of the late Sidney Greenbaum at University College London, which planned corpora for a geographically widespread cross-section of local Englishes: not just England, the USA, and Canada, but also the Caribbean and Jamaica, Hong Kong, Singapore, India, Kenya-Tanzania-Zimbabwe, Nigeria, the Philippines, and South Africa (Greenbaum, 1991). These corpora would provide, for the first time in history, a base of authentic data about local varieties of English that have hitherto led a contradictory existence of being used by large populations but not appropriately recognised as valid alternative language systems.

These corpora might allow us to explore how the meaning of key terms, such as 'democracy' and 'democratic', is being continually worked out in discursive practices. One heuristic we might apply to the Corpus of South African English (hereafter CSAE) would be to examine the collocational tendencies or collocabilities, defined as the preferences of discourse participants regarding how lexicogrammatical resources are typically selected and combined during discourse, as we can infer them from the actual 'collocations', defined as an array of interactive linguistic choices that are distinctly more likely than average to occur together (cf. Firth, 1968: 186, 111, 182f, 106ff, 113; Greenbaum, 1974), e.g. 'multiracial democracy' in [15] or 'committed freedom fighter' in [58]. Still, no matter how large a corpus becomes, we will always encounter some "patterns for which there is some evidence, but insufficient to make a conclusive case for significance' (Sinclair, 1991: 491).

Admittedly, the Corpus of South African English is still rather small. Like the other ICE corpora, its original target size was one million words, but it has since been increased to around three million. The current corpus comprises the ICE material, plus material from the Independent Online News Service and the Mail and Guardian Online on the Internet, the home pages of South African political parties, and a collection of spoken data for which we deeply indebted to Sue Watermeyer, who was trained by the well-known sociolinguist Raj Mesthrie at the University of Capetown. Having over 700,000 words from spoken data from private conversations, class lessons and lectures, business transactions, legal cross-examinations, parliamentary debates, and broadcast interviews, discussions, news, and sports commentaries might be highly significant for seeing how terms like 'democratic' are used outside public spotlights. In future research, the data such as those presented below might 
productively be factored according to political settings and historical periods, as well as sources, registers, audiences, and possibly even individual speakers or writers

Meanwhile, the present report must obviously be regarded as a programmatic exploration, intended not to draw firm conclusions about 'South African English' but merely to indicate what we ourselves intuitively judge to be interesting evidence such a corpus can offer about the discourse of a society undergoing a sweeping transition. We still need far more data from a far wider range of sources and regions before we can address, let alone answer, such key questions as how 'democracy' will be defined in practice and not just in theory.

Now let us look at some CSAE data on the central terms 'democracy' and 'democratic' themselves. Not surprisingly, these terms returned plenty of attestations - 184 and 244 respectively although we can safely disregard the 65 occurrences of 'Democratic' in self-chosen names of organisations, usually political, where the meaning is conveniently non-committal or merely pretentious (e.g. for Mr Mangope's dubious 'United Christian Democratic Party'). The remaining data do provide us with numerous productive signals of how the term is being contextualised in South African discourse. At least three familiar conceptions could be detected:

(a) a doctrine of equality in human rights and in personal and civil liberties;

(b) a political system of 'majority rule' by means of a secure electoral machinery with multiple parties and universal voting rights,

(c) an economic system of free enterprise and equal opportunity in the economy and the job market.

At the start of this section, we proposed a definition of 'democracy' centred squarely upon the first conception (a). The assumption that all three conceptions are fully compatible and have in fact been successfully integrated in the 'modern Western' societies of Europe and North America is a popular and reassuring notion, but one South Africans might well regard with extreme caution. 'Majority rule' in conception (b) is by no means a safe guarantee of equality in human rights; history provides a daunting gallery of demonstrations of how a majority can dole out harshly undemocratic treatment to minorities. Surely few South Africans would suggest that the institutionalised racism in the USA prior to the civil rights legislation of the 1960s was 'democratic' just because it happened to have been approved there by a white majority. In the South African context, at all events, the supreme test for the new 'democracy' will be for all of the groups, sharply divided by a long and troubled history of conflict, to grant each other the rights and respect each group wants for themselves. As we shall see, the CSAE data indicate a wide spread of attitudes and expectations about this test.

Even greater caution should be exercised about the full compatibility of democracy with an economic system of 'free enterprise'. Martin and Schumann's (1996: 311) prodigiously researched exposé of 'globalisation' summarises the current situation in these terms:

Now what the founders of the post-war welfare states had learned from bitter experience is becoming ever more clearly visible: free-market economy and democracy are by no means inseparable blood-brothers, who harmoniously nourish prosperity for everyone. Instead, the two central guiding models of the old industrial states of West stand in constant contradiction to each other.

Some prominent authorities in economics and political science (e.g. Reich, 1993; Barber, 1996) has marshalled evidence that the linkage of these two conceptions may well have been a transitory historical accident during a specific stage of 'modernisation' requiring a wide expansion of participation in production and consumption of modestly priced mass commodities, whereas current conditions since about 1980 favour a converse concentration upon high-priced elite commodities. In parallel, the real control over the so-called 'free market capitalism' is now reserved for overpowering multinational corporations and managements. Aided by circuitous tax havens and write-offs, they not only contribute little or no tax-base to support democratic institutions like public education and social security in their host countries, but liberally extract public tax monies in the guise of the 'investment incentives' whereby prospective hosts are forced to bid against each other for production plants and to reduce or abolish worker benefits, safety measures, pension plans, pollution controls, and so on (Martin \& Schumann, 1996). 
In view of these considerations, the representation of the three conceptions of 'democracy' in our CSAE data may offer some noteworthy signals of current and future developments. ${ }^{2}$ The conception of equality in human rights was well documented in contexts supplying a brisk range of concepts (called 'cornerstones', 'principles', 'values', etc.), including 'human rights, justice, peace, economic development' [1], 'non-racism, non-sexism' [2], 'social justice and fundamental human rights' [3], 'universal adult suffrage, a national common voters roll, regular elections, and a multi-party system' [4] or 'renewal, sport, youth, tolerance' [5]. Some data even signalled a feeling of having set a historical milestone in the advance of 'democracy' [6-7], albeit with minor uneasiness about 'tension' [7] and the 'crime rate' and 'corruption' [8] (compare the 'life and death struggle against crime' in sample [58] below)

[1] lists of 'cornerstones' - more than 20 in all - including human rights, democracy, justice, peace, Africa, economic development.

[2] to further the interests of the practitioner in the field of adult continuing education and training. AETASA [Amalgamated English Teachers Association of South Africa] is committed to the principles of non-racism, non-sexism, democracy and sustainable development and further believes that historical imbalances in the provision of adult education and training should be addressed as a priority.

[3] establish a society based on democratic values, social justice and fundamental human rights; Lay the foundations for a democratic and open society in which government is based on the will of the people and every citizen is equally protected by law

[4] Universal adult suffrage, a national common voters roll, regular elections, and a multiparty system of democratic government, to ensure accountability, responsiveness and openness. Supremacy of Constitution

[5] historic moment with friends internationally while we celebrate worthwhile things like renewal, sport, youth, tolerance, and democracy. $<\mathrm{P}>$ One of the mechanisms for success is the South African resolve to hold a uniquely developmental Games in Capetown.

[6] but also discrimination based on gender, sexual orientation and religion. Ironically, while the historic 'cradles of democracy' still agonise over an Equal Rights Amendment, the South African constitution guarantees women equal rights.

[7] Accept contradictions, tension two years after the arrival of political democracy, South Africa boasts a model liberal democratic constitution which has few peers in the world community.

[8] citizens today are proud to be South Africans. Perhaps it is because all South Africans have helped to bring about a democracy and have participated in its rituals. It may also mean that in spite of the disastrous crime rate, the gravy train accusations and the perennial reports of corruption

We shall return to overtones linking democracy to 'economic development' later on.

Predictably, the CSAE data signalled a conscious determination, ranging from mild to intense, to turn away from the past [9-15], e.g. via a 'shift' [10], a 'new style' [11], a 'reinstatement' or even a 'quantum blast' [12]. The terms for invoking the past also ranged from mild and abstract, e.g. 'divisions' [9], 'authoritarian past [10], 'huge problems' [11], 'exclusive privileges' [12], to concrete and intense, e.g. 'accumulated racist muck' [13], and 'massacre of the innocent' [14]. Amid this chorus of voices, the admonition of ' $\mathrm{FW}$ ' (i.e. de Klerk) [15] of might sound like an invitation to forget the past when his ruling Nationalist Party busily tried to plant apartheid behind every bush.

[9] constitution as the supreme law of the Republic so as to heal the divisions of the past and establish a society based on democratic values, social justice and fundamental human rights; Lay the foundations for a democratic and open society

[10] of your staff. There needs to be a shift from the mentality that we inherited from our authoritarian past toward a democratic mentality of self-empowered reflexivity. When it comes to the ideological paradigm shift 
[11] that a developing country with the complexities and huge problems of ours should develop a new style of participatory democracy not to frustrate or restrict the majority but to involve more parties at leadership level in the decision making

[12] the learned professor has heard of the wise words 'justice delayed is justice denied'. That is what the new democracy is all about - a reinstatement of social justice for the majority and a diminution of exclusive privileges for the white minority

[13] for much too long. Contrary to the professor's view, what is imperative is a quantum blast of democracy strong enough to flush out the Augean Stables of three centuries of accumulated racist muck

[14] people had to consolidate their victory. $<\mathrm{P}>$ "The task is to shift the balance of forces irreversibly in favour of peace, democracy, and development. Real heroes and heroines will emerge from the battle for peace, democracy and development and not in the massacre of innocent and unarmed children and women, old men and women," he added.

[15] Now that South Africa had established a non-discriminatory multiracial democracy, South Africans had to come to terms with their cultural diversity and stop looking for apartheid behind every bush, says FW

A shift of such magnitude brings with it a vital mandate for education both as an explicit subject and a methodological orientation [16-17]. The 'boom in English teaching' [18] when many schools are being slashed by rationalisation' (samples [44-45] below) may seem an irony of history if we recall the earlier vision of English as a language of resistance to the Afrikaner regimes (cf. reports and references in Smit 1994); also, calling it the 'new lingua franca' sounds quaint when it has been aggressively promoted as such world-wide for well over a century.

[16] The South African Institute For Distance Education (SAIDE) is a dynamic NGO [nongovernment organisation] committed to increasing democratic access to knowledge, learning and skills through the adoption of open learning principles and distance education

[17] like to enrol as full-time or part-time students for a $\mathrm{Ph} \mathrm{D}, \mathrm{M} \mathrm{Ed}$ or $\mathrm{B} \mathrm{Ed}$, with research specialisation in the area of democracy, human rights and citizenship education. $<\mathrm{p}>$ Who should apply? Teachers, curriculum specialists, publishers, materials developers and researchers with an interest in human rights education in teaching for democratic citizenship

[18] English to foreigners becomes a big business $<\mathrm{B}>15 / 6 / 97</ \mathrm{B}>$ By Karen Mac Gregor, Education Editor $<\mathrm{P}>$ Democratic change has sparked a countrywide boom in English teaching, with demand for South Africa's new lingua franca increasing rapidly

Again predictably, concerns about the 'fragile' quality of the new system have been raised, e.g., whether voting rights will be effectively used [19-20], whether political parties will transcend racial divisions [21], whether proper time schedules can be maintained [22-23], whether democratic concepts will be 'learned' and 'understood' and not just reduced to 'buzzwords' people hardly 'understand' [2425], and whether the rights of the rest will be respected by the voting majority [26-27]. Interestingly, at least some voices recognised the lesson of history, cited above, that a majority may abuse its "natural" right to prevail' [26] and enforce a 'winner-takes-all approach' [27]; and that a majority 'referendum' on a complex human issue like 'capital punishment' is quite 'superficial' [28], the more so in a country once notorious for its 'hanging judges'.

[19] Democracy is a fragile concept and if it is to work, it is vital that each registered voter makes use of this fundamental right

[20] There are still all sorts of problems to be resolved before people use their democratic right to elect their representatives to local councils and there is a whole education programme still needed

[21] If the support of political parties is not going to grow across all ethnic and racial divides our democracy will become more and more polarised more and more one dimensional and sterile 
[22] While every effort must be made to meet the deadline to ensure that our transformation to full democracy is not unnecessarily delayed, extreme caution must be exercised to ensure that the fundamentals of a new society for which so much has been sacrificed, are not compromised

[23] Again the media reported last week that Schlemmer felt democracy was moving too rapidly in South Africa. At what speed must a positive influence move to eliminate a scourge?

[24] Our entire society is on a steep learning curve trying to build a new democracy and we must take steps to tighten financial controls, discipline offenders and strengthen our institutions.

[25] I'd like to conclude uh Mr Chairman <\#> Uh the buzzword of the day in our country is democracy <\#> It is truth <\#> It is reconciliation <\#> It is nation building <\#> You don't understand those concepts and you don't understand how to operationalise those concepts

[26] the sense of common community, of 'we-ness', is very fragile and certainly not strong for what the ANC calls 'an ordinary democracy', ie, where a simple majority has got the 'natural' right to prevail

[27] divided and polarised country like South Africa should not take over the typical European and classical form of democracy. Instead of the winner-takes-all approach we argued that a developing country with the complexities and huge problems of ours should develop a new style

[28] Superficially, the referendum which will test public opinion, presents itself as the most democratic instrument to determine the future of capital punishment

A particularly sensitive issue in the overall 'transformation to full democracy' [22] is the new role of the media like press and radio. Recalling a past of 'hiding and misleading' [29], the data signalled a desire here too for 'diversity' and 'openness' [30] and for 'liberalisation', the latter naturally alluring to 'foreign investors' hungry for 'commercial radio licences' [31] in our era of monstrous media conglomerates (Barber 1994). Yet caution was expressed about media becoming exploitive and intrusive enough to occasion new modes of 'injustice' [32].

[29] how the apartheid state's control of the airwaves attempted to hide and mislead people about the horrors of apartheid. A democratic state requires a diversity of voices to be heard so that citizens can make informed decisions

[30] The demand for diversity of voices in a democracy needs to be translated into a diversity of radio and $T V$ stations. This means opening the airwaves to a range of broad

[31] to soothe the impatience of foreign investors who have been eyeing South Africa ever since the first moves towards democracy in 1990 promised a liberalisation $\langle p\rangle\langle p\rangle$ Matisonn hopes that the first independent commercial radio licence

[32] To allow a trial by the media would be a great injustice. We would be undermining a cornerstone of our new democracy: innocent until proven guilty

The widespread linkage between democracy and economic growth or development found in our CSAE data may not be surprising, since we may have noticed it already in several data samples [1-12, 5, 31]. Among the more transparent instances were [33-38]. Some data might create the impression that the 'business' community needs to give its permission for democracy to succeed [36-38] probably a far less absurd prospect than you might imagine if 'economic development' is to be the yardstick of 'democratic' progress (compare samples [1-2]). Notice the favourite capitalist message (akin to Reaganism and Thatcherism) that the goal of 'business' and 'economic stability' is 'a better future for all' [35] and not just for the rich, although the situation to be 'stabilised' in South Africa currently consists of sharp economic inequalities that naturally promote instability. At least the 'trade unions' are well aware that special efforts are urgently needed if a 'live economy' is to sustain 'democracy in workplaces' [38] and that the Foundation's pious proclaimation of 'Growth for All' [39] should be critically viewed against similar slogans of Reaganism and Thatcherism, cited above.

[33] the resources and potential of a country and those of its people will not be available for a coherent programme of reconstruction and development. The linking of democracy and development and the emphasis on a people-centred approach are a deliberate strategy to pave the way for a new democratic order 
[34] to address long-neglected problems of development and reconstruction. $<\mathrm{P}>$ There is a new emphasis on the need for democratic government in Africa to go hand-in-hand with economic advance.

[35] Social stability and the prospect of a better future for all, are the bedrock not just of a stable democracy, but also of a stable economy. $<\mathrm{P}>$ For business, opportunities abound

[36] possibly attracting business support. At the very least it would inject dynamism into the democracy we have set up.

[37] Initiative is an organisation formed by 130 companies to enhance the business contribution to Growth, Development and Democracy in South Africa. A key element of its programme is to work through its members to create local economic development

[38] as business and employers we say spread the culture of investing in our people <\#> Investing in our live economy and bring democracy to our workplaces <\#> Let us make no mistake <\#> Strong and democratic trade unions are permanent and desirable features

[39] Labour's head-on response to the South Africa Foundation's Growth for All strategy is evidence of attempts by the democratic movement to get its act together and regain lost ground.

Just one occurrence in the current CSAE touched openly upon the antagonism between of 'democracy' versus 'capitalism', and only to attenuate it in ways that would be congenial for the journal 'Finance Week':

[40] flinched when Manuel quoted market mover billionaire George Soros as saying unbridled capitalism was the enemy of democracy. What Soros actually said, Finance Week summarised, was that excessive individualism in the pursuit of wealth would

By contrast, a frank picture emerged several times when we queried the key-word 'rationalisation'. In theory, the term 'rationalisation' sounds reassuring by association with 'rational', a trait most people would like to believe they possess and a reasonable imperative for business, as suggested in [41]; and it apparently sounds more soothing and 'neutral' than 'privatisation' [42], not to mention honestly realistic terms like 'lusting for profit' or 'siphoning money from workers to shareholders'. But most of our CSAE data indicated that most of its practical consequences are, on the contrary, alarming [43-47].

[41] employees along the new strategic objectives. His problem is clear: "We have inherited over 16 000 workers; rationalisation is not just about numbers, but rather about creating high levels of efficiency through appropriate skills.

[42] privatisation would provoke knee-jerk opposition from the labour movement and that a more neutral word, such as rationalisation, would be more palatable.

[43] Job cuts, plant closures, disposals and mergers have abounded as global players attempt to rationalise their businesses and become more focused.

[44] The teachers were unanimous that the uncertainty over rationalisation had taken its toll on morale and that this was manifesting itself in classrooms and affecting their work.

[45] In terms of the rationalisation programme $\mathbf{6 , 0 0 0}$ teachers are to lose their jobs in Western Cape schools this year. $<\mathrm{P}>$ Staff cuts do not end there.

[46] In these days when public medical services are being severely compromised by the rationalisation of funds and facilities, there are many loyal, committed professional medical personnel who are worthy of special commendation

[47] Mr Lionel Woldson, general manager of the Child Welfare Society in Cape Town, said yesterday: "We've rationalised to the point where we can deal only with abused and neglected children under the age of 12 .

[48] The police service overspent R604-million, mainly because of the rationalisation of police services

If 'rationalisation' has indeed 'become more focused' [43], then evidently focused hardships upon the victims it targets: teachers and their pupils [44-45], the ill or disabled [46], and 'abused and neglected children' who have committed the offence of being 'over the age of 12' [47]! We were fascinated to 
see a major exception where 'rationalisation' brings huge increases in expenditure in 'police services', doubtless being beefed up to repress the waves of crime and violence that mass lay-offs have consistently been observed to trigger in other nations. What clearer evidence could we find for the real attitude of business and capitalism toward human rights and respect for ordinary citizens than the eagerness to kick them out of their jobs and to surround the victims of economic inequality with more and more 'police services'?

What conclusions might we draw about the general modes and attitudes of South African citizens regarding the course of their young 'democracy', as far as our very limited data sampling might offer some signals? A diversity of voices spanned a wide range: real optimism that more has been achieved than has been properly 'communicated' or than the 'constant carping' would suggest [49]; subdued optimism of learning from past mistakes [50]; 'terrible doubts' [51]; and pessimistic visions of failure and stagnation [52-55], the latter often gauged precisely in terms of 'economic policies' and 'investments from overseas' [55], which are probably much on the minds of the 'privileged chattering classes' [49] and of the residents of 'palaces and fortified mansions' [51].

[49] the idea that little has changed for ordinary people owes more to the failure of bodies charged with communicating the achievements of the democratic Government, as well as the constant carping of our privileged chattering classes, who appear more terrified than thrilled by the prospect and reality of change. South Africa's democratic transformation, the hyperbolic touting of its miraculous character notwithstanding, has indeed been exciting

[50] From the faults come lessons, however, which may help establish the culture of democracy and may ensure fewer problems next time. $\langle \#>A$ report by the Community Elections Evaluation Group, which analysed the November local government elections, seeks to do

[51] the people who lived in palaces and fortified mansions would relieve their suffering? <\#> Terrible doubts obsessed my mind as I thought: Democracy may merely be a trick by those who want to hoodwink the populace. $\langle/ \mathrm{p}\rangle\langle \#\rangle\langle$ p $>$ I was indeed puzzled by the bizarre claim that we were about to enter a paradise of democracy: all we had to do was vote for those we believed would do the job.

[52] constituencies unfamiliar with the body politic emerging from apartheid structures. Rightly or wrongly, the advent of democracy has largely not been seen to deliver on election promises. In Northern Province, people are still galled

[53] Dr Vincent Maphai, the executive director of the HSRC, notes that the political honeymoon of South Africa's new democratic government has faded much faster than was the case with Zimbabwe and Namibia after their independence.

[54] not delivering on housing. <\#> The disillusionment of voters gulled by fanciful election promises is a common feature of democracy, but South Africa's troubled society may lack the reserves to roll with punches like these.

[55] the government's constitutional plans have failed because their new constitution is taking us further away from true democracy $<\&>$ The government's economic policies are failing because there are no significant investments from overseas

Pessimism also surfaced regarding the doubtful integrity of political agents:

[56] I felt that I was, had been, and will continue to be a committed freedom fighter. $<\#>$ What would a mere vote mean? <\#> For me, the very idea of democracy had been debased by those who shouted the word and were either dictators or simply inept leaders.

[57] nepotism and corruption are not trivial issues, and those in government better be quick in grasping this fact. Our democracy will be seriously undermined if those in leadership send out the signal that the name of the game is to look out only for yourself

[58] nepotism played a major role in the sad saga of how that country snatched national degradation and poverty out of the jaws of great potential and vast resources. $<\mathrm{P}>$ Our democracy's current life and death struggle against crime will certainly not be won by a government perceived to be corrupt and incompetent 
[59] not doing what a technical/opportunistic society bids them to do, which is to use their democratic rights to stamp, complain, and shout about the injustices of 'preferred' hirings of party family members and relations

A curious counterpoint might be diagnosed if protests about nepotism get linked with 'opportunism' and get derisively termed 'stamp, complain, and shout' [59], as if the content were totally unimportant.

\section{Conclusion and outlook}

In the previous section, we have attempted to illustrate with documented discursive practices in contemporary South Africa some of the more theoretical prospects raised in the opening section. If, as we have argued, language and discourse are central to the construction and negotiation of social reality, working with authentic corpus data can be valuable resource in tracking the evolution of a society and deserves to become a strategic component of language education and policy-making programmes, especially ones expressly committed to promoting understanding and respect for democracy, as documented in samples [16-17].

Although our data sets presented here are quite modest, they do allow us to supplement or revise our own personal intuitions about how the meanings of terms and concepts like 'democracy' and 'democratic' are currently being negotiated within a range of discourses in South Africa among social groups who pursue adaptive values for their respective goals. We have seen that some meanings of 'democracy' are linked not to human equality and mutual respect of human rights, but to the machinery of amassing 'votes', or else to the attainment of 'economic growth' which has so far certainly not been 'for all' (cf. sample [39]). We have also seen evidence that the inclusive theory of 'democracy' is not perceived in some quarters to have been put into inclusive practice, although the motives and obstacles have been diagnosed in divergent ways.

Just as a true democracy cannot consist merely of a majority exercising a 'winner-take-all' approach (cf. sample [27]), a truly democratic view of language, discourse, and meaning cannot simply conclude that humanly vital terms like 'democracy' must have just those meanings most often implied by powerful, vocal media, e.g., by ones who want the term to mean their own 'freedom' to maximise profits by 'privatising' the sectors which pay well and 'rationalising' away those which, like 'public medical services' and 'welfare societies', do not (cf. [43-47]). The consensus for a new and genuine democracy in South Africa necessarily calls for a new sensitivity to support inclusive theories and practices of discourse within the society, and encourage the many decisions to be made in favour of democracy.

Further, the consensus implies a corresponding mandate for linguistics and language education programmes not to be brutally 'rationalised' out of our universities on the grounds - not entirely unjustified, as can be seen from the considerations raised in section 1 - of having turned away from real language in favour of empty abstract idealisations. On the contrary, such programmes should be broadened and deepened to seize the historical opportunity for assuming a key role in cultivating that very sensitivity. All the required resources and efforts of the schools and universities, community centres, citizens' groups, mass media, and electronic internets must be exerted to unite the citizens in strategically promoting the 'transformation to full democracy' ([22]) just where its future may well be most crucially decided: in language and in discourse.

If the Corpus of South African English is to be one such resource, it will have to be greatly enlarged and developed in order to help us define and describe the potential group-specific varieties characterised by such factors as age, race, social class, profession, education, and place of residence, which could be justly be asked from a truly sensitive indicator and gauge of the evolution of a multicultural society. Only then can such a corpus be a real tool for building democratic discourse among South Africans in the years ahead as they discursively work to construct and elaborate their new identity as a genuinely modern and democratic nation.

\section{Notes}


${ }^{1}$ This report was partially drafted by the first author when he was sequestered at the Vienna General Hospital awaiting and then recuperating from surgery in August 1997. At that time, he was a visiting scholar at the University of Botswana at Gaborone. The corpus data had been culled in July 1997 during his visit to University of Port Elizabeth with the assistance of the second author, who later on returned to the by then enlarged corpus to complement the first set of data.

${ }^{2}$ In the data, $<p>$ marks the end of a paragraph in material taken from Internet. $<\#>$ marks the end of a sentence in written data, and of a 'text unit' in spoken data, the latter inevitably admitting of some differences in interpretation by intonational or semantic criteria.

\section{REFERENCES}

BARBER, B. Coca Cola und Heiliger Krieg: Wie Kapitalismus und Fundamentalismus Demokratie und Freiheit abschaffen. Bern: Scherz Verlag. 1996a.

BEAUGRANDE, R. de. "The 'pragmatics' of doing language science: The 'warrant' for large-corpus linguistics". Journal of Pragmatics, v. 25, p. 503-535. $1996 \mathrm{~b}$.

BEAUGRANDE, R. de. New Foundations for a Science of Text and Discourse. Greenwich, CT: Ablex. 1997.

BEAUGRANDE, R. de. "Society, education, linguistics, and language: Inclusion and exclusion in theory and practice". Linguistics and Education, v. 9, n. 2, p. 99-158, 1998.

BEAUGRANDE, R. de. "Theory versus practice in language planning and in the discourse of language planning". World Englishes, v. 18, n. 2, p. 107-121, 1999.

CHOMSKY, N. Syntactic Structures. The Hague: Mouton. 1957.

CHOMSKY, N. Aspects of the Theory of Syntax. Cambridge: M.I.T. Press. 1965.

EDELMAN, G. Brilliant Air, Bright Fire: On the Matter of the Mind. New York: Basic Books. 1992.

FIRTH, J.R. Selected Papers of J.R. Firth 1952-1959, ed. F.R. Palmer. London: Longman. 1968.

FRANCIS, G.; SINCLAIR, J.McH. "I bet he drinks Carling Black Label: A riposte to Owen on corpus Grammar". Applied Linguistics, v.15, p. 190-200. 1994.

GERE, A.R.; SMITH, E. Attitudes, Language, and Change. Urbana: National Council of Teachers of English. 1979.

GREENBAUM, S. "Some verb-intensifier collocations in American and British English". American Speech, v. 49, p. 79-89. 1974

GREENBAUM, S. The International Corpus of English. London: University College Technical Report. 1991

HALLIDAY, M.A.K. Language in a Changing World. Sidney: Australian Association of Applied Linguistics. 1994.

MARTIN, H.-P.; SCHUMAN, H. Die Globaliserungsfalle: Der Angriff auf Demokratie und Wohlstand. Reinbeck: Rowohlt. 1996. 
OWOMOYELA, O. The African Difference: Discourses on Africanity and the Relativity of Culture. New York: Peter Lang. 1996.

PHILLIPSON, R. Linguistic Imperialism. Oxford: Oxford University Press. 1992

REICH, R.B. The Work of Nations: Preparing for 21st-Century Capitalism. New York: Simon and Schuster. 1993

SAUSSURE, F. de. [orig. 1916]. Course in General Linguistics, transl. W. Baskin. New York: McGraw-Hill. 1969.

SINCLAIR, J.McH. "Shared knowledge". In ALATIS, (Ed.), Georgetown University Round Table on Languages and Linguistics 1991. Washington: Georgetown University Press, 1991. p. 489-500. 